\title{
TREE SPECIES OF THE CENTRAL AMAZON AND SOIL MOISTURE ALTER STABLE ISOTOPE COMPOSITION OF NITROGEN AND OXYGEN IN NITROUS OXIDE EVOLVED FROM SOIL
}

\author{
O. V. MENYAILO ${ }^{\mathrm{a}, *}$, B. A. HUNGATE ${ }^{\mathrm{b}}, \mathrm{J}^{\text {. LEHMANN }}{ }^{\mathrm{c}}$, \\ G. GEBAUER ${ }^{\mathrm{d}}$ and W. ZECH ${ }^{\mathrm{c}}$ \\ ${ }^{\mathrm{a}}$ Institute of Forest SB RAS, Krasnoyarsk, Russia; ${ }^{\mathrm{b}}$ Department of Biological Sciences and \\ Merriam-Powell Center for Environmental Research, Northern Arizona University, Flagstaff, USA; \\ ${ }^{\mathrm{c} D e p a r t m e n t}$ of Soil Science and Soil Geography, University of Bayreuth, Bayreuth, Germany; \\ ${ }^{\mathrm{d}}$ Department of Plant Ecology, University of Bayreuth, Bayreuth, Germany
}

(Received 30 June 2002; In final form 28 October 2002)

\begin{abstract}
The use of stable isotopes of $\mathrm{N}$ and $\mathrm{O}$ in $\mathrm{N}_{2} \mathrm{O}$ has been proposed as a way to better constrain the global budget of atmospheric $\mathrm{N}_{2} \mathrm{O}$ and to better understand the relative contributions of the main microbial processes (nitrification and denitrification) responsible for $\mathrm{N}_{2} \mathrm{O}$ formation in soil. This study compared the isotopic composition of $\mathrm{N}_{2} \mathrm{O}$ emitted from soils under different tree species in the Brazilian Amazon. We also compared the effect of tree species with that of soil moisture, as we expected the latter to be the main factor regulating the proportion of nitrifier- and denitrifierderived $\mathrm{N}_{2} \mathrm{O}$ and, consequently, isotopic signatures of $\mathrm{N}_{2} \mathrm{O}$.

Tree species significantly affected $\delta^{15} \mathrm{~N}$ in nitrous oxide. However, there was no evidence that the observed variation in $\delta^{15} \mathrm{~N}$ in $\mathrm{N}_{2} \mathrm{O}$ was determined by varying proportions of nitrifier- $v s$. denitrifier-derived $\mathrm{N}_{2} \mathrm{O}$. We

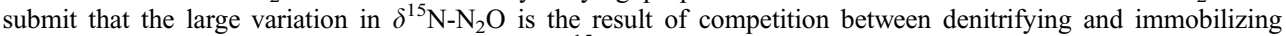
microorganisms for $\mathrm{NO}_{3}^{-}$. In addition to altering $\delta^{15} \mathrm{~N}-\mathrm{N}_{2} \mathrm{O}$, tree species affected net rates of $\mathrm{N}_{2} \mathrm{O}$ emission from soil in laboratory incubations. These results suggest that tree species contribute to the large isotopic variation in $\mathrm{N}_{2} \mathrm{O}$ observed in a range tropical forest soils. We found that soil water affects both ${ }^{15} \mathrm{~N}$ and ${ }^{18} \mathrm{O}$ in $\mathrm{N}_{2} \mathrm{O}$, with wetter soils leading to more depleted $\mathrm{N}_{2} \mathrm{O}$ in both ${ }^{15} \mathrm{~N}$ and ${ }^{18} \mathrm{O}$. This is likely caused by a shift in biological processes for ${ }^{15} \mathrm{~N}$ and possible direct exchange of ${ }^{18} \mathrm{O}$ between $\mathrm{H}_{2} \mathrm{O}$ and $\mathrm{N}_{2} \mathrm{O}$.
\end{abstract}

Keywords: Denitrification; Natural variations; Nitrification; Nitrogen 15; Nitrous oxide; Oxygen 18; Tree species; Tropical soils

\section{INTRODUCTION}

The increase in the atmospheric concentration of nitrous oxide $\left(\mathrm{N}_{2} \mathrm{O}\right)$ has attracted considerable scientific attention from different disciplines during the last 10-15 years, because $\mathrm{N}_{2} \mathrm{O}$ is one of the major greenhouse gases and also participates in the destruction of the ozone layer [1]. Denitrification and nitrification are the main biological processes leading to $\mathrm{N}_{2} \mathrm{O}$ formation and emission from the soil. Understanding the relative contributions

\footnotetext{
* Corresponding author. Department of Biological Sciences, Northern Arizona University, Flagstaff, AZ 86011-5640, USA. E-mail: menyailo@hotmail.com
} 
of each process to total $\mathrm{N}_{2} \mathrm{O}$ emission is critical for modeling and predicting changes in $\mathrm{N}_{2} \mathrm{O}$ fluxes under varying environmental conditions, including altered temperature and precipitation patterns. Denitrification is known to be favored when soils are moist and anaerobic, whereas nitrification is favored under more mesic to xeric conditions. The sources of $\mathrm{N}_{2} \mathrm{O}$ can be identified using selective inhibitors, sterilization, or by adding substrates [2], but all of these methods are destructive and intrusive, and thus may not accurately reflect the sources of $\mathrm{N}_{2} \mathrm{O}$ [3]. Another possible way to identify the processes producing $\mathrm{N}_{2} \mathrm{O}$ is to study fluctuations in the isotopic composition of $\mathrm{N}_{2} \mathrm{O}$ around natural abundance [4,5]. The isotopic composition provides a window through which we may understand biological processes underlying $\mathrm{N}_{2} \mathrm{O}$ emission from the soil, since the isotopic composition (i.e. ratios of ${ }^{15} \mathrm{~N} /{ }^{14} \mathrm{~N}$ and ${ }^{18} \mathrm{O} /{ }^{16} \mathrm{O}$ ) of denitrifier-derived $\mathrm{N}_{2} \mathrm{O}$ differs from that of nitrifier-derived $\mathrm{N}_{2} \mathrm{O}$ $[6,7]$. Despite the potentially high value of the knowledge of isotopic composition, there are very few published data and a general lack of understanding of the mechanisms and extent of isotopic fractionation of $\mathrm{N}_{2} \mathrm{O}$. For example, a large variation of stable isotopes in $\mathrm{N}_{2} \mathrm{O}$ is currently interpreted as a different contribution of nitrification and denitrification without any information on activities of these processes. $\mathrm{N}_{2} \mathrm{O}$ produced by nitrification is often more depleted in ${ }^{15} \mathrm{~N}$ than that produced by denitrification, leading to the suggestion that the $\delta^{15} \mathrm{~N}$ composition of $\mathrm{N}_{2} \mathrm{O}$ emitted from the soil is thought to reflect the relative contributions of nitrification and denitrification to the total $\mathrm{N}_{2} \mathrm{O}$ flux $[4,7-10]$. The picture is complicated by $\mathrm{N}_{2} \mathrm{O}$-reductase, which also selects light $\mathrm{N}_{2} \mathrm{O}$ for reduction to $\mathrm{N}_{2}$, enriching the remaining un-reacted $\mathrm{N}_{2} \mathrm{O}$ in ${ }^{15} \mathrm{~N}$, and thereby further contributing to the more positive $\delta^{15} \mathrm{~N}$ values associated with denitrification [8]. The scarcity of the available information is also explained by methodological difficulties and the large air sample volume $(\sim 100 \mathrm{~L})$ necessary for ${ }^{15} \mathrm{~N}$ and ${ }^{18} \mathrm{O}$ measurements. Recent advances in sample preparation procedure [11] promise rapid growth of the data and deeper understanding of $\mathrm{N}_{2} \mathrm{O}$ fluxes and underlying processes.

Tropical forest soils are known to be one of the main natural sources of $\mathrm{N}_{2} \mathrm{O}$ [12]. In recent years, large tracts of tropical rain forests have been subjected to conversion to grasslands or tree-based agroforestry systems. Tree species altering soil microbial processes would also be expected to affect the isotopic composition of $\mathrm{N}_{2} \mathrm{O}$. Pérez et al. [13] measured the stable isotopic composition of $\mathrm{N}_{2} \mathrm{O}$ evolved from soils in tropical rain forests, and observed large spatial heterogeneity in $\delta^{15} \mathrm{~N}$ and $\delta^{18} \mathrm{O}$ values in $\mathrm{N}_{2} \mathrm{O}$. Here, we evaluate whether the influence of individual tree species on soil processes contributes to this observed variation in the stable isotopes of $\mathrm{N}_{2} \mathrm{O}$ evolved from soil. We also compared the effects of tree species with that of soil moisture, as moisture is likely to influence the proportion of nitrifier- and denitrifier-derived $\mathrm{N}_{2} \mathrm{O}$ and, consequently, the isotopic signatures of $\mathrm{N}_{2} \mathrm{O}$. We expected that, at low soil moisture, nitrification would be the main source of $\mathrm{N}_{2} \mathrm{O}$, leading to depleted $\delta^{15} \mathrm{~N}$ values, and that denitrification, in contrast, would prevail at high soil moisture, leading to enrichment of $\delta^{15} \mathrm{~N}$. Variation in soil moisture was used to alter the relative contribution of denitrification and nitrification to $\mathrm{N}_{2} \mathrm{O}$ efflux. Because of potential influence of $\mathrm{N}_{2} \mathrm{O}$-reductase on stable isotopes in $\mathrm{N}_{2} \mathrm{O}$, its activity was measured in all soils. For this, $\mathrm{C}_{2} \mathrm{H}_{2}$ inhibition technique in anaerobic incubation experiments was used. We assumed that soils with the highest potential $\mathrm{N}_{2} \mathrm{O}$ reduction capacity would also have the strongest effect of $\mathrm{N}_{2} \mathrm{O}$-reductase on stable isotopes in $\mathrm{N}_{2} \mathrm{O}$ under anaerobic conditions.

\section{MATERIALS AND METHODS}

\section{Research Site}

The experimental plots of the Empresa Brasileira de Pesquisa Agropecuaria (Embrapa Amazonia Ocidental) are located $40 \mathrm{~km}$ north of Manaus (Central Amazon). The soil type 
is a Xanthic Ferralsol [14], which is typical for the "terra firme" ecosystems of the Central Amazon, Brazil. The climate is humid tropical with an average annual precipitation of $2503 \mathrm{~mm}$. This soil is characterized by a high clay content $(80 \%)$, low nutrient content and an acidic reaction $(\mathrm{pH}<4.5)$.

The experiment was set up in a completely randomized block design with three blocks, each consisting of four plots. The plots were established on an abandoned rubber plantation after slash and burn for the tree cropping systems (one plot with timber and one with non timber species) and the secondary forest (one plot). Adjacent to the three plots was another plot within the natural forest; together these four plots constituted one block. We analyzed the data using a completely randomized design, where species was the only treatment, assuming thus that there is no block effect.

The studied trees were two non-timber tree species - Bixa orellana L. (annatto; used as natural dye), Theobroma grandiflorum Willd. (ex Spreng.) K. Schum. (cupuaçu; for icecream and juice production), growing together on the one plot, and two species planted for wood production - Carapa guianensis Aubl (andiroba) and Ceiba pentandra (growing together on second plot). Plots with secondary forests consisted of 1 species - Vismia sp. In the plots of primary forest two species were chosen - Oenocarpus bacaba and Eschweilera spp. Both trees are typical of the terra firme forest.

Bixa was planted in rows with $4 \mathrm{~m}$ distance in the row and Theobroma with $7 \mathrm{~m}$ alternating with Brazil nut (Bertholletia excelsa Humb. Bonpl.). Total planting density was 93.3 and 156.3 trees ha $^{-1}$ for Theobroma and Bixa, respectively. At the natural forest sites no other tree species were closer than $4 \mathrm{~m}$ from the stem of the tested species, so neighboring trees likely had little effect on the microbial activities or soil chemistry compared to Oenocarpus and Eschweilera. The tree plantations and the secondary forest were 7 years old at the time of the experiment.

In February 1999, soil cores at $0-5 \mathrm{~cm}$ depth were taken at $50 \mathrm{~cm}$ distance from tree stems using a soil auger. We took 4 soil samples under two trees in each plot and these 8 samples were mixed. All the 21 soil samples ( 3 aggregated samples for each of the 7 species) were airdried, sieved $(2 \mathrm{~mm})$ and transported to the laboratory.

\section{Incubation Experiments}

As $\mathrm{N}_{2} \mathrm{O}$-reductase may significantly affect $\delta^{15} \mathrm{~N}$ values in $\mathrm{N}_{2} \mathrm{O}$ [13], its activity was measured according to [15]. In short, soil samples were moistened with distilled water and preincubated at $28^{\circ} \mathrm{C}$ during 3 days. $1 \mathrm{ml}$ of water solution with $\mathrm{KNO}_{3}$ and glucose was added to $5 \mathrm{~g}$ of soil in $20 \mathrm{ml}$ flask. The resulting concentration of nitrate was $40 \mathrm{mg} \mathrm{NO}_{3}$ $\mathrm{N} \mathrm{kg} \mathrm{soil}^{-1}$, that of glucose, $100 \mathrm{mg} \mathrm{C} \mathrm{kg}^{-1}$ soil. Anaerobiosis was achieved by replacing the headspace of each flask with He and sealing with airtight rubber stoppers and clamps. Half of the sub-samples received $2.5 \mathrm{ml}(10 \% \mathrm{v} / \mathrm{v})$ of $\mathrm{C}_{2} \mathrm{H}_{2}$ as an inhibitor of $\mathrm{N}_{2} \mathrm{O}$-reductase. Soil samples were incubated for 96 hours at $28^{\circ} \mathrm{C}$. After $6,12,24,48,72$ and $96 \mathrm{~h}$, the headspace of each flask $(1 \mathrm{ml})$ was sampled for the analysis of $\mathrm{N}_{2} \mathrm{O}$ using gas chromatography (GC) - Shimadzu 14A, equipped with electron capture detector $\left(\mathrm{ECD}^{63} \mathrm{Ni}\right)$. Results were recorded as $m g \mathrm{~N}_{2} \mathrm{O}-\mathrm{N} \mathrm{kg}^{-1}$. Activity of $\mathrm{N}_{2} \mathrm{O}$ reduction to $\mathrm{N}_{2}$ was calculated as a difference between $\mathrm{N}_{2} \mathrm{O}$ production without and with $\mathrm{C}_{2} \mathrm{H}_{2}$.

A separate aerobic incubation experiment was conducted to study the isotopic composition of $\mathrm{N}_{2} \mathrm{O}$. For this, $20 \mathrm{~g}$ of each soil sample was placed in $100 \mathrm{ml}$ glass flasks, moistened with distilled water and pre-incubated at $28^{\circ} \mathrm{C}$ during 3 days to initiate microbial activities. After that, a distilled water solution with $\mathrm{NH}_{4} \mathrm{NO}_{3}$ was added to each flask to increase the concentration of inorganic $\mathrm{N}$ to $500 \mathrm{mg} \mathrm{NH}_{4} \mathrm{NO}_{3}-\mathrm{N} \mathrm{kg}^{-1}$. Soil moisture contents were adjusted to be $30 \%, 60 \%$ and $90 \%$ of the water holding capacity (WHC). The flasks were closed with 
airtight rubber stoppers, fixed with clamps, and than incubated for $72 \mathrm{~h}$. During the incubation the headspace of each flask was sampled at $24 \mathrm{~h}, 48 \mathrm{~h}$ and $72 \mathrm{~h}$ (last time point was not measured in soils under Ceiba, Oenocarpus and Vismia). At each sampling, we removed $1 \mathrm{ml}$ of the headspace to determine $\mathrm{N}_{2} \mathrm{O}$ concentrations using $\mathrm{GC}$ as described above and $5 \mathrm{ml}$ of headspace to determine the isotopic composition of $\mathrm{N}_{2} \mathrm{O}$ using a coupled gas chromatograph/isotope-ratio mass spectrometer (GC-IRMS). The $5 \mathrm{ml}$ samples were injected in $100 \mathrm{ml}$ glass containers filled with He, stored (1-2 days), and after that measured on the GC-IRMS. In contrast to the first experiment, this second incubation experiment involved: i) aerobic conditions and neither glucose nor $\mathrm{C}_{2} \mathrm{H}_{2}$ application to allow nitrification to take place, ii) addition of $\mathrm{NH}_{4} \mathrm{NO}_{3}$ instead of $\mathrm{KNO}_{3}$ to promote both nitrification and denitrification, and iii) three moisture levels to obtain a range of proportions of nitrifierand denitrifier-derived $\mathrm{N}_{2} \mathrm{O}$. We expected that increasing soil moisture should increase the proportion of $\mathrm{N}_{2} \mathrm{O}$ derived from denitrification and decrease $\mathrm{N}_{2} \mathrm{O}$ from nitrification.

\section{Isotopic Measurements in $\mathbf{N}_{\mathbf{2}} \mathrm{O}$}

The ratios of the stable isotopes ${ }^{15} \mathrm{~N} /{ }^{14} \mathrm{~N}$ and ${ }^{18} \mathrm{O} /{ }^{16} \mathrm{O}$ in $\mathrm{N}_{2} \mathrm{O}$ emitted from soils were determined using an on-line GC-IRMS system, consisting of a trace gas cryogenic preconcentration device (PreCon, FINNIGAN MAT, Bremen), gas chromatograph (Hewlett-Packard 5890, Series II), and an isotope-ratio mass spectrometer (Delta S, FINNIGAN MAT, Bremen).

Ion currents corresponding to $\mathrm{m} / \mathrm{z} 44,45$ and 46 were used to obtain the ratios of masses 45:44 and 46:44 in $\mathrm{N}_{2} \mathrm{O}$ samples were measured which were then used to estimate ratios of ${ }^{15} \mathrm{~N}^{14} \mathrm{~N}^{16} \mathrm{O} /{ }^{14} \mathrm{~N}_{2}{ }^{16} \mathrm{O}$ and ${ }^{14} \mathrm{~N}_{2}{ }^{18} \mathrm{O} /{ }^{14} \mathrm{~N}_{2}{ }^{16} \mathrm{O}$. Other combinations of the isotopes of $\mathrm{N}$ and $\mathrm{O}$ were discounted because they are so rare that their contributions to the 45 and 46 mass peaks are negligible [11]. The isotopic composition was expressed using the $\delta$ notation, in which increasingly larger $\delta$ values (less negative) indicate enrichment of the heavier isotope $\left({ }^{15} \mathrm{~N}\right.$ or ${ }^{18} \mathrm{O}$ ) in the sample $\mathrm{N}_{2} \mathrm{O}$ relative to that in the reference:

$$
\delta=\frac{R_{\text {sample }}-R_{\text {reference }}}{R_{\text {reference }}} \times 1000 \%
$$

where $R$ is the ratio ${ }^{15} \mathrm{~N} /{ }^{14} \mathrm{~N}$ or ${ }^{18} \mathrm{O} /{ }^{16} \mathrm{O}$.

We used $\mathrm{N}_{2} \mathrm{O}$ as a working reference gas (99.9990\%, Linde), with $\delta^{15} \mathrm{~N}$ determined via reduction to $\mathrm{N}_{2}$ under copper at $1150^{\circ} \mathrm{C}$. This signature was then compared to an IAEAcalibrated $\mathrm{N}_{2}$ reference gas. The $\delta^{18} \mathrm{O}$ signature of the reference $\mathrm{N}_{2} \mathrm{O}$ was determined by comparison with $\mathrm{CO}_{2}$ of known $\delta^{18} \mathrm{O}$.

\section{Statistical Data Analysis}

The first incubation experiment was performed with two replications for each sample. The effects of species, time and $\mathrm{C}_{2} \mathrm{H}_{2}$ treatment and their interactions were determined by three-way ANOVA (repeated measures design) with 3 replicates (means of two measurements for each of three soil samples under each species). The second incubation experiment was done without replicates because determination of isotopes in $\mathrm{N}_{2} \mathrm{O}$ is still very timeconsuming process ( $20 \mathrm{~min}$ for one measurement), thus yielding 3 replicates ( 3 soil samples for 1 tree species). Because of an incomplete design (some isotope data were missing and under three species the $72 \mathrm{~h}$ point was not measured), and because our primary interest was effect of species and moisture, we considered time as replicate and not as a factor. The effects of species and moisture on ${ }^{15} \mathrm{~N}$ and ${ }^{18} \mathrm{O}$ in $\mathrm{N}_{2} \mathrm{O}$ were calculated with two-way 
ANOVA. Where the main effect was significant, the post hoc comparison with Turkey test was performed to identify which species and/or what moisture level differed significantly. We considered the effect significant at $P<0.05$. All statistics were carried out with the statistical package STATISTICA [16].

\section{RESULTS}

\section{$\mathrm{N}_{2} \mathrm{O}$-reductase Activity}

Cumulative $\mathrm{N}_{2} \mathrm{O}$ production measured in the $\mathrm{N}_{2} \mathrm{O}$-reductase incubation experiment (with and without $\mathrm{C}_{2} \mathrm{H}_{2}$ ) and calculated $\mathrm{N}_{2} \mathrm{O}$ consumption are presented in Figure 1(A). All three factors (species, time, presence of $\mathrm{C}_{2} \mathrm{H}_{2}$ ) strongly affected the amount of $\mathrm{N}_{2} \mathrm{O}$ produced (for all, $P<0.001)$.

Over the entire $96 \mathrm{~h}$ incubation with the $\mathrm{C}_{2} \mathrm{H}_{2}$ treatment, soils under Theobroma and Carapa produced $43-85 \mathrm{mg} \mathrm{N}_{2} \mathrm{O}-\mathrm{N} \mathrm{kg}^{-1}$, significantly more than soils from under the other species. Soils from under Bixa, Ceiba, Eshweilera, Oenocarpus, and Vismia, did not differ in $\mathrm{N}_{2} \mathrm{O}$ production with added $\mathrm{C}_{2} \mathrm{H}_{2}$, accumulating between 28 and $54 \mathrm{mg} \mathrm{N} \mathrm{N}_{2} \mathrm{O}-\mathrm{N} \mathrm{kg}^{-1}$ during the $96 \mathrm{~h}$ incubation period.

In all soils, except under Carapa, net $\mathrm{N}_{2} \mathrm{O}$ accumulation (without $\mathrm{C}_{2} \mathrm{H}_{2}$ ) was positive for all measurement times, indicating that $\mathrm{N}_{2} \mathrm{O}$-reductase activity was lower than the activity of $\mathrm{N}_{2} \mathrm{O}$-producing enzymes. Only under Carapa did $\mathrm{N}_{2} \mathrm{O}$ concentration begin to decline after $72 \mathrm{~h}$, at which point the rate of $\mathrm{N}_{2} \mathrm{O}$ reduction exceeded the rate of $\mathrm{N}_{2} \mathrm{O}$ production. Low but detectable $\mathrm{N}_{2} \mathrm{O}$ reduction occurred in all soils after 24 hours, except from Oenocarpus, where $\mathrm{N}_{2} \mathrm{O}$ reduction was not detected until after 48 hours. The rate of $\mathrm{N}_{2} \mathrm{O}$ reduction increased with time under Theobroma and Carapa, but not for the other species. By the end of the incubation period, soils under Theobroma and Carapa had consumed about $50 \%$ of the total amount of $\mathrm{N}_{2} \mathrm{O}$ produced during the $96 \mathrm{~h}$ incubation. Thus, isotopic discrimination by $\mathrm{N}_{2} \mathrm{O}$-reductase is most likely to be apparent in soils beneath Theobroma and Carapa.

\section{Net $\mathbf{N}_{2} \mathrm{O}$ Production}

Net $\mathrm{N}_{2} \mathrm{O}$ production during the aerobic incubation experiment is presented in Figure 1(B). Species $(P<0.001)$ and moisture $(P=0.025)$ affected $\mathrm{N}_{2} \mathrm{O}$ production, but the effects of species depended on moisture content (interaction, $P=0.050$ ). For example, soils under Ceiba and Oenocarpus formed the highest amount of $\mathrm{N}_{2} \mathrm{O}$ at $30 \%$ and $60 \%$ WHC, respectively, while soils under other species produced higher amount of $\mathrm{N}_{2} \mathrm{O}$ at the highest moisture content $(90 \% \mathrm{WHC})$.

The slight decrease in net $\mathrm{N}_{2} \mathrm{O}$ accumulated with time was observed only under Carapa at $72 \mathrm{~h}$ and $90 \% \mathrm{WHC}$. This might be attributed to $\mathrm{N}_{2} \mathrm{O}$-reductase activity, given that the highest potential $\mathrm{N}_{2} \mathrm{O}$-reductase activity was also observed under Carapa.

\section{Net $\mathrm{CO}_{2}$ Production}

The rate of $\mathrm{CO}_{2}$ production during the second aerobic incubation experiment with varying moisture levels is presented in Figure 2. The $\mathrm{CO}_{2}$ production was strongly affected by tree species $(P<0.001)$, but not by soil moisture. Ceiba, Oenocarpus and Vismia produced more $\mathrm{CO}_{2}$ than all other species $(P<0.001)$. 


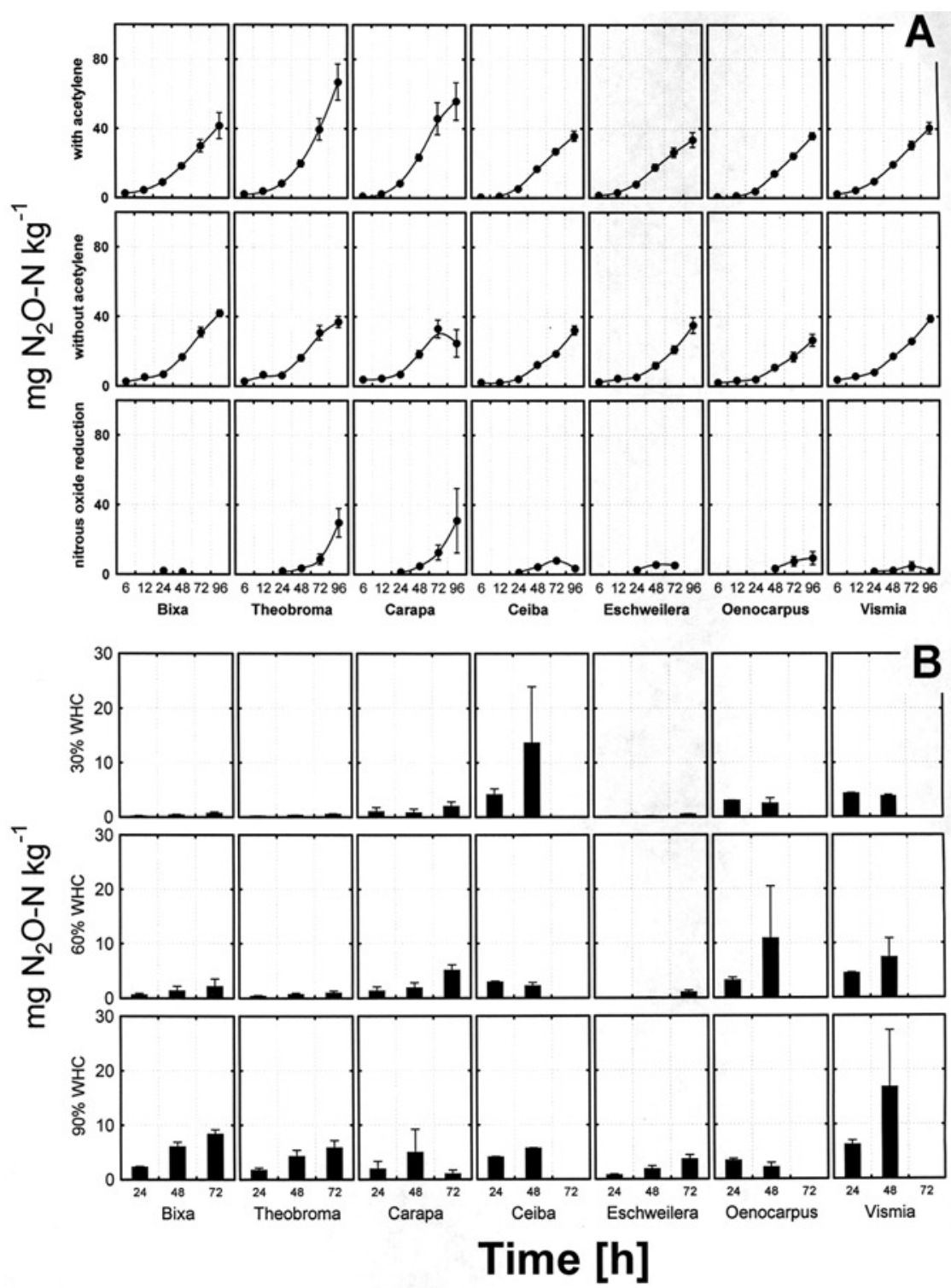

FIGURE 1 (A) Net $\mathrm{N}_{2} \mathrm{O}$ production $\left(\mathrm{mg} \mathrm{N}_{2} \mathrm{O}-\mathrm{N} \mathrm{kg}^{-1}\right.$ ) during anaerobic incubation in the presence and absence of $\mathrm{C}_{2} \mathrm{H}_{2}$, and $\mathrm{N}_{2} \mathrm{O}$ reduction activity (calculated as the difference between $\mathrm{N}_{2} \mathrm{O}$ concentration with and without $\mathrm{C}_{2} \mathrm{H}_{2}$ ). The symbols indicate means \pm standard errors $(n=3)$. (B) $\mathrm{Net}_{2} \mathrm{O}$ production $\left(\mathrm{mg} \mathrm{N}_{2} \mathrm{O}-\mathrm{N} \mathrm{kg}^{-1}\right)$ of soils beneath different tree species in Brazilian Amazon during aerobic incubation under three soil moisture levels (means and standard errors; $n=3$ ).

\section{$\delta^{15} \mathrm{~N}$ Signature in $\mathrm{N}_{2} \mathrm{O}$}

Measured $\delta^{15} \mathrm{~N}-\mathrm{N}_{2} \mathrm{O}$ values varied in our soils from -37.8 to $2.7 \%$ (Fig. 3(A)). The $\delta^{15} \mathrm{~N}$ values were significantly affected by tree species $(P<0.001)$ and by soil moisture $(P=0.030)$ with significant interaction between these factors $(P=0.033)$, indicating that the tree species had a different effect on the isotopic composition of $\mathrm{N}-\mathrm{N}_{2} \mathrm{O}$ at different levels of soil moisture content. Species affected $\delta^{15} \mathrm{~N}-\mathrm{N}_{2} \mathrm{O}$ only at 30 and $60 \%$ of WHC. At $30 \%$

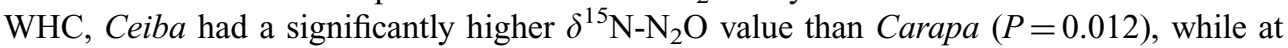




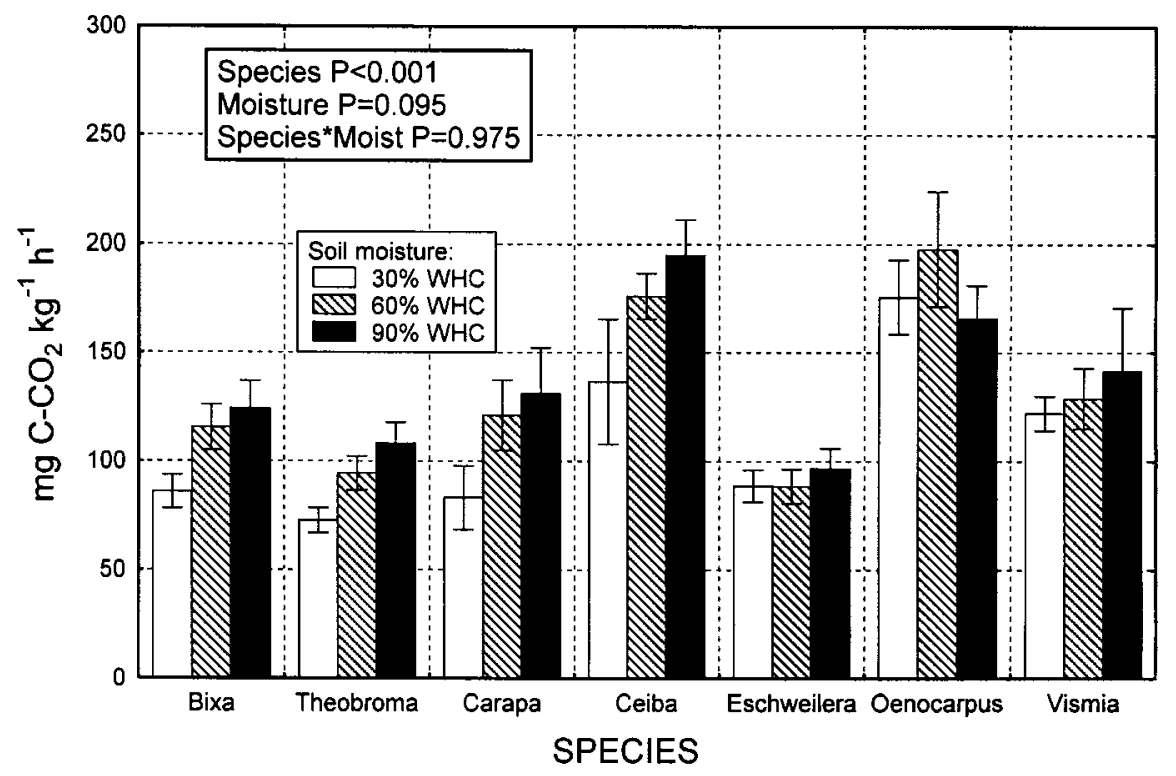

FIGURE 2 The rate of $\mathrm{CO}_{2}$ production $\left(\mathrm{mg} \mathrm{CO}_{2}-\mathrm{C} \mathrm{kg}^{-1} \mathrm{~h}^{-1}\right)$ in soils beneath different tree species in the Brazilian Amazon during aerobic incubation under three soil moisture levels. Values are means \pm standard errors $(n=3)$

$60 \%$ WHC, Ceiba and Oenocarpus had higher $\delta^{15} \mathrm{~N}-\mathrm{N}_{2} \mathrm{O}$ values than all other species except Eschweilera $(P=0.058)$.

Overall, considering all moisture levels together, the heaviest nitrogen in $\mathrm{N}_{2} \mathrm{O}$ was under Ceiba $(-9.3 \pm 2.6 \%, N=10)$ and Oenocarpus $(-9.8 \pm 2.4 \%$ o, $N=9)$. The values significantly differed from all other species $(P<0.001)$. The most depleted $\delta^{15} \mathrm{~N}_{-} \mathrm{N}_{2} \mathrm{O}$ was under Carapa $(-23 \pm 2 \%, N=15)$ and Theobroma $(-20 \pm 1.4 \%, N=9)$; these values however did not significantly differ from those found under Bixa, Eschweilera and Vismia.

As stated above, water contents strongly affected nitrogen isotopes in $\mathrm{N}_{2} \mathrm{O}$ (Fig. 4), with decreasing $\delta^{15} \mathrm{~N}$ values as soil water content increased. The significant difference in $\delta^{15} \mathrm{~N}$ was between $30 \%$ and $90 \%$ of WHC $(P=0.010)$.

\section{$\delta^{18} \mathrm{O}$ Signature in $\mathrm{N}_{2} \mathrm{O}$}

Measurements in our soils showed larger variation in $\delta^{18} \mathrm{O}-\mathrm{N}_{2} \mathrm{O}$ (from -21.2 to $45.8 \%$ ) than in $\delta^{15} \mathrm{~N}-\mathrm{N}_{2} \mathrm{O}$ (Fig. 3(B)). Tree species did not affect $\delta^{18} \mathrm{O}$ in $\mathrm{N}_{2} \mathrm{O}(P=0.222)$, whereas soil moisture had a highly significant effect $(P<0.001)$. In contrast to $\delta^{15} \mathrm{~N}$, no interaction between tree species and soil moisture was found $(P=0.227)$, suggesting that the effects of soil moisture on $\delta^{18} \mathrm{O}$ in $\mathrm{N}_{2} \mathrm{O}$ are similar under all tree species. Overall, $\delta^{18} \mathrm{O}$ decreased with increasing soil water content, the same pattern as that found for $\delta^{15} \mathrm{~N}$ (Fig. 4). The $\delta^{18} \mathrm{O}-\mathrm{N}_{2} \mathrm{O}$ values at $90 \%$ WHC were lower than those at 30 and $60 \%$ WHC (for both, $P<0.001$ ).

\section{DISCUSSION}

\section{Species Effect on $\delta^{15} \mathrm{~N}-\mathrm{N}_{2} \mathrm{O}$}

Measured $\delta^{15} \mathrm{~N}-\mathrm{N}_{2} \mathrm{O}$ values varied from -37.8 to $2.7 \%$, nearly in the same range as recently reported for tropical forest soils in Costa Rica and Brazil - from -34 to 2\%o [13]. We found a 

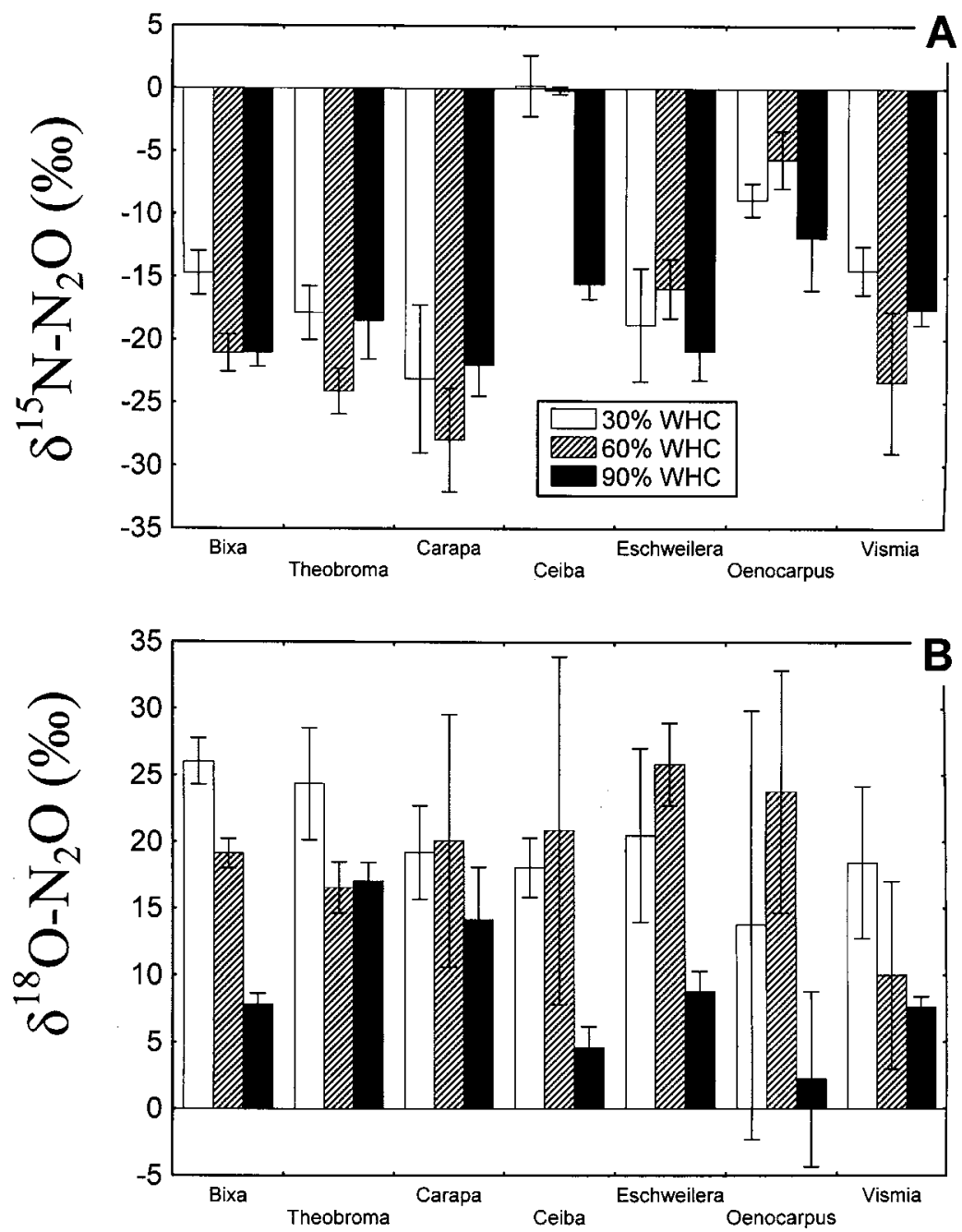

FIGURE $3 \quad \delta^{15} \mathrm{~N}(\mathrm{~A})$ and $\delta^{18} \mathrm{O}$ (B) in $\mathrm{N}_{2} \mathrm{O}(\%)$ produced by soils beneath different tree species in Brazilian Amazon during aerobic incubation at three soil moisture levels. Values are means \pm standard errors $(n=3)$

strong effect of tree species: soils under Ceiba and Oenocarpus produced 10-25\%o heavier $\delta^{15} \mathrm{~N}-\mathrm{N}_{2} \mathrm{O}$ than the other species. The significant differences in the isotopic composition of $\delta^{15} \mathrm{~N}-\mathrm{N}_{2} \mathrm{O}$ suggest different microbiological processes responsible for $\mathrm{N}_{2} \mathrm{O}$ production under different species.

We found that Ceiba and Oenocarpus had the lowest values of denitrification potential and the highest rates of $\mathrm{CO}_{2}$ production. However, the higher relative contribution of nitrification to $\mathrm{N}_{2} \mathrm{O}$ flux under these species seems unlikely because nitrification should discriminate more against the heavy isotope of $\mathrm{N}$ in $\mathrm{N}_{2} \mathrm{O}$, producing $\mathrm{N}_{2} \mathrm{O}$ with $\delta^{15} \mathrm{~N}$ that is approximately $30 \%$ more negative than those associated with denitrification $[4,13,17]$. In contrast, the $\delta^{15} \mathrm{~N}$ values of $\mathrm{N}_{2} \mathrm{O}$ produced under Ceiba and Oenocarpus were more positive than the other species. $\mathrm{N}_{2} \mathrm{O}$-reductase was also unlikely to have contributed to $\delta^{15} \mathrm{~N}$ discrimination, as its activity was low under these species.

We suspect that $\mathrm{NO}_{3}^{-}$immobilization affected $\delta^{15} \mathrm{~N}-\mathrm{N}_{2} \mathrm{O}$ by leading to substrate limitation of denitrification. Isotope discrimination is strongest when substrates are non-limiting [18]. 


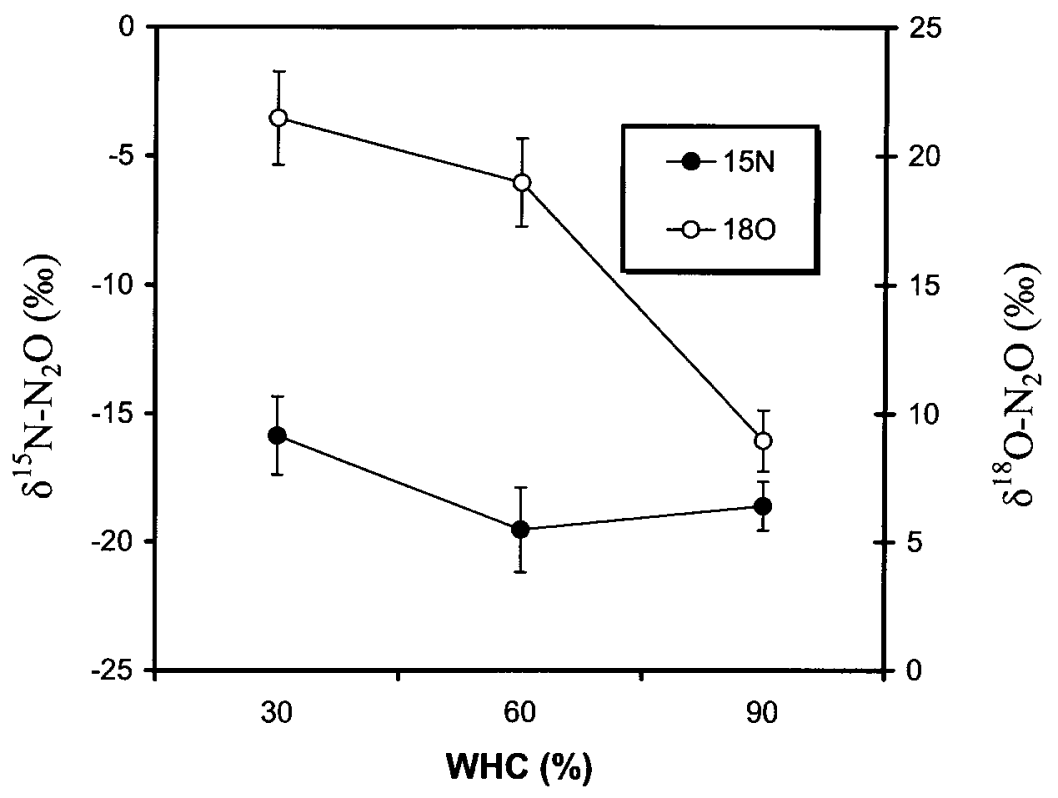

FIGURE 4 Effects of soil moisture content on $\delta^{15} \mathrm{~N}$ and $\delta^{18} \mathrm{O}(\%)$.

If denitrification was the main source of $\mathrm{N}_{2} \mathrm{O}$ produced under Ceiba and Oenocarpus even at 30 and $60 \% \mathrm{WHC}$, and in these soils denitrification was limited by $\mathrm{NO}_{3}^{-}$availability due to the high activity of heterotrophic $\mathrm{C}$-mineralizing microorganisms, one would expect the isotope effects during denitrification to be relatively small and the $\delta^{15} \mathrm{~N}-\mathrm{N}_{2} \mathrm{O}$ values to be more positive. Another possible explanation is that discrimination against ${ }^{15} \mathrm{~N}$ during microbial immobilization of $\mathrm{NO}_{3}^{-}$enriched the remaining $\mathrm{NO}_{3}^{-}$in $\delta^{15} \mathrm{~N}$ values, leading to the more positive $\delta^{15} \mathrm{~N}-\mathrm{N}_{2} \mathrm{O}$ observed, which is likely high under Ceiba and Oenocarpus. Fractionation during $\mathrm{NO}_{3}^{-}$immobilization remains poorly understood and will require further investigation. However, published values for isotopic discrimination against ${ }^{15} \mathrm{~N}$ during nitrate and ammonium assimilation are near 10\%o [19-21]. Thus, fractionation during $\mathrm{NO}_{3}^{-}$immobilization may partly explain the difference in $\delta^{15} \mathrm{~N}-\mathrm{N}_{2} \mathrm{O}$ values under Ceiba and Oenocarpus.

Based on published data for isotopic effects during denitrification, the differences between $\delta^{15} \mathrm{~N}-\mathrm{N}_{2} \mathrm{O}$ and $\delta^{15} \mathrm{~N}-\mathrm{NO}_{3}^{-}$should be $13-28 \%$ [8,22]. The isotope effect measured in our study for 5 species were thus in the reported range (18-25\%), if we assume that $\delta^{15} \mathrm{~N}$ values of $\mathrm{NO}_{3}^{-}$applied were around $0 \%$ as typically found for man-made fertilizers. The difference in $\delta^{15} \mathrm{~N}-\mathrm{N}_{2} \mathrm{O}$ between Ceiba and Oenocarpus and all other species were 10-25\%, a slightly smaller difference possibly due to $\mathrm{NO}_{3}^{-}$limitation of denitrification resulting in a smaller isotope effect.

Thus, the observed effect of the species on $\delta^{15} \mathrm{~N}-\mathrm{N}_{2} \mathrm{O}$ was likely caused not by differences in the proportion of nitrifier- $v$. denitrifier-derived $\mathrm{N}_{2} \mathrm{O}$, but rather by differences among plant species in their effects on soil $\mathrm{NO}_{3}^{-}$immobilization.

\section{Soil Moisture Effect on Stable Isotopes in $\mathrm{N}_{2} \mathrm{O}$}

We expected to observe an increase in $\delta^{15} \mathrm{~N}-\mathrm{N}_{2} \mathrm{O}$ values with increasing soil moisture due to increase in denitrifier-derived $\mathrm{N}_{2} \mathrm{O}$. However, we observed the opposite pattern, with increasing 
soil moisture further depleting $\delta^{15} \mathrm{~N}-\mathrm{N}_{2} \mathrm{O}$ values. Hence, this pattern is very unlikely due to a shift in nitrification/denitrification ratio. Even if most $\mathrm{N}_{2} \mathrm{O}$ formed at $90 \%$ of WHC was derived from denitrification, the observed depletion in $\delta^{15} \mathrm{~N}-\mathrm{N}_{2} \mathrm{O}$ could be due to a greater isotope effect due to reduced substrate limitation by nitrate-immobilizing microorganisms. However, the data on $\mathrm{CO}_{2}$ production do not directly support this conclusion, as soil moisture had no effect on $\mathrm{CO}_{2}$ production. The possible explanation could be that microorganisms change the preference for assimilation of inorganic $\mathrm{N}$ forms from $\mathrm{NO}_{4}^{+}$to $\mathrm{NO}_{3}^{-}$as soil moisture increases. This would result in higher $\mathrm{NO}_{3}^{-}$limitation to denitrification at higher soil moisture. However, testing this hypothesis requires further research.

Whereas tree species did not alter $\delta^{18} \mathrm{O}-\mathrm{N}_{2} \mathrm{O}$, increasing soil moisture caused a decline in $\delta^{18} \mathrm{O}-\mathrm{N}_{2} \mathrm{O}$. Compared to $\delta^{15} \mathrm{~N}$ values, less data are available in the literature on $\delta^{18} \mathrm{O}$ variation in $\mathrm{N}_{2} \mathrm{O}$. The $\delta^{18} \mathrm{O}$ in $\mathrm{N}_{2} \mathrm{O}$ formed by nitrification may reflect the isotopic signatures hydroxylamine, molecular oxygen and soil water [13]. The $\delta^{18} \mathrm{O}$ of denitrifier-derived $\mathrm{N}_{2} \mathrm{O}$ should reflect the isotopic composition of $\mathrm{NO}_{3}^{-}$, the substrate for denitrification. The reported values for oxygen fractionation during denitrification differ significantly. For example, Barford [23] estimated an $\varepsilon$ of $105 \%$, assuming no interaction of oxygen isotopes between $\mathrm{N}_{2} \mathrm{O}$ and $\mathrm{H}_{2} \mathrm{O}$. Wahlen and Yoshinari [9] determined that, during $\mathrm{N}_{2} \mathrm{O}$ reduction by denitrifying organisms, ${ }^{18} \mathrm{O}$ gets heavier by a range of 37 to $42 \%$.

Measurements in our soils revealed a larger variation in $\delta^{18} \mathrm{O}-\mathrm{N}_{2} \mathrm{O}$ (from -21.2 to $45.8 \%$ ) than in $\delta^{15} \mathrm{~N}-\mathrm{N}_{2} \mathrm{O}$. These values covered also a wider range than reported for $\delta^{18} \mathrm{O}$ by Pérez et al. [13]: from -4 to $18 \%$. One of the possible explanations is the wider range of soil moisture contents in our incubation experiments (30-90\% WHC) than in the fields where Pérez et al. conducted their measurements (57-95\%, WFPS).

The reduction in $\delta^{18} \mathrm{O}$ values with increasing soil moisture may have been caused by direct exchange of oxygen between $\mathrm{N}_{2} \mathrm{O}$ and $\mathrm{H}_{2} \mathrm{O}$. In contrast to ${ }^{15} \mathrm{~N}$, the largest difference in $\delta^{18} \mathrm{O}$ was between the mesic and highest soil water content, providing evidence that the direct effect of soil water on ${ }^{18} \mathrm{O}$ in $\mathrm{N}_{2} \mathrm{O}$ is likely the more important factor affecting $\delta^{18} \mathrm{O}$ in these soils. If we assume that all $\mathrm{N}_{2} \mathrm{O}$ was derived from denitrification and that $\mathrm{N}_{2} \mathrm{O}$ consumption did not affect the isotopic signatures in $\mathrm{N}_{2} \mathrm{O}$, the soil water seems to be important factor even during denitrification. This may be caused by exchange of ${ }^{18} \mathrm{O}$ of water with oxygen in $\mathrm{N}_{2} \mathrm{O}$ and/or $\mathrm{NO}_{3}^{-}$. We suggest that the effect of soil moisture on $\delta^{18} \mathrm{O}-\mathrm{N}_{2} \mathrm{O}$ values likely results from different levels of equilibration of oxygen isotopes between $\mathrm{N}_{2} \mathrm{O}$ and $\mathrm{H}_{2} \mathrm{O}$. However, the $\delta^{18} \mathrm{O}$ values of water and nitrate used in our studies were not known, limiting our ability to understand the mechanisms causing variation in $\delta^{18} \mathrm{O}-\mathrm{N}_{2} \mathrm{O}$ values. Nevertheless, the different patterns of response to soil moisture and tree species observed for $\delta^{15} \mathrm{~N}$ and $\delta^{18} \mathrm{O}$ in $\mathrm{N}_{2} \mathrm{O}$ would suggest different mechanisms affecting both isotopes, biological for ${ }^{15} \mathrm{~N}$ and physical (direct exchange) for ${ }^{18} \mathrm{O}$.

\section{CONCLUSIONS}

To our knowledge, this is the first study to show that plant species significantly affect ${ }^{15} \mathrm{~N}$ in nitrous oxide evolved from soil. This is probably due to tree-mediated changes in microbiological activities. These effects of individual tree species might contribute to the variation in $\delta^{15} \mathrm{~N}-\mathrm{N}_{2} \mathrm{O}$ values observed in tropical forest soils [13]. However, there was no evidence that ${ }^{15} \mathrm{~N}$ in $\mathrm{N}_{2} \mathrm{O}$ was determined by the relative contributions of nitrification and denitrification in $\mathrm{N}_{2} \mathrm{O}$ efflux. Based on $\delta^{15} \mathrm{~N}-\mathrm{N}_{2} \mathrm{O}$ measurements the differences among species may have been due to (a) $\mathrm{NO}_{3}^{-}$limitation for denitrification caused by immobilization or (b) fractionation during nitrate immobilization. However, both explanations require experimental verification. 
Nevertheless, our results suggest that the variation in $\delta^{15} \mathrm{~N}$ values in $\mathrm{N}_{2} \mathrm{O}$ observed under field conditions may not be very useful in distinguishing the relative contributions of nitrification and denitrification to $\mathrm{N}_{2} \mathrm{O}$ flux. Other processes, i.e. immobilization and related nitrate limitation, could affect isotopes in $\mathrm{N}_{2} \mathrm{O}$. The $\delta^{15} \mathrm{~N}-\mathrm{N}_{2} \mathrm{O}$ values could indicate the strength of competition between denitrifying and nitrate immobilizing microorganisms. Finally, we demonstrated that soil water content affects the stable isotopic composition of $\mathrm{N}$ and $\mathrm{O}$ in $\mathrm{N}_{2} \mathrm{O}$ evolved from soil, possibly due to both effects of water content on microbial activities and due to oxygen exchange between $\mathrm{H}_{2} \mathrm{O}$ and $\mathrm{N}_{2} \mathrm{O}$.

Overall, analysis of stable isotopes in nitrous oxide has potential to lend insight to soil nitrogen cycling and the mechanisms of $\mathrm{N}_{2} \mathrm{O}$ turnover. But before this method can be effectively used in the field, much work remains to be done to fully characterize the factors contributing to $\mathrm{N}_{2} \mathrm{O}$ fractionation.

\section{Acknowledgements}

This work was supported by the German Research Foundation (DFG) and by the GermanBrazilian SHIFT project supported by grants from the German Ministry of Science, Education and Technology (BMBF) and the Brazilian National Research Agency (CNPq). The Fulbright Program, the US National Science Foundation, and the Merriam-Powell Center for Environmental Research provided support during the writing of this manuscript.

\section{References}

[1] Crutzen, P. J. (1981). Atmospheric chemical processes of the oxides of nitrogen, including $\mathrm{N}_{2} \mathrm{O}$. In: Delwiche, C. C. (Ed.), Denitrification, Nitrification, and Atmospheric Nitrous Oxide. Wiley, New York, pp. 17-44.

[2] Davidson, E. A. and Schimel, J. P. (1995). Microbial processes of production and consumption of nitric oxide, nitrous oxide and methane. In: Matson, P. A. and Harris, R. C. (Eds.), Biogenic Trace Gases: Measuring Emission from Soil and Water. University Press, Cambridge, pp. 327-357.

[3] Stevens, R. J., Laughlin, R. J., Burns, L. C., Arah, J. R. M. and Hood, R. C. (1997). Measuring the contributions of nitrification and denitrification to the flux of nitrous oxide from soil. Soil Biol. Biochem., 29, 139-151.

[4] Yoshida, N. (1988). ${ }^{15} \mathrm{~N}$-depleted $\mathrm{N}_{2} \mathrm{O}$ as a product of nitrification. Nature, 335, 528-529.

[5] Yoshinari, T. (1990). Emissions of $\mathrm{N}_{2} \mathrm{O}$ from various environments - the use of stable isotope composition of $\mathrm{N}_{2} \mathrm{O}$ as tracer for the studies of $\mathrm{N}_{2} \mathrm{O}$ biogeochemical cycling. In: Revsbech, N. P. and Sorensen, J. (Eds.), Denitrification in Soil and Sediment. Plenum Press, New York, pp.129-150.

[6] Kim, K. Y. and Craig, H. (1990). Two-isotope characterization of $\mathrm{N}_{2} \mathrm{O}$ in the Pacific Ocean and constraints on its origin in deep water. Nature, 347, 58-61.

[7] Webster, E. A. and Hopkins, D. W. (1996). Nitrogen and oxygen isotope ratios of nitrous oxide emitted from soil and produced by nitrifying and denitrifying bacteria. Biol. Fertil. Soils, 22, 326-330.

[8] Barford, C. C., Montoya, J. P., Altabet, M. A. and Mitchell, R. (1999). Steady-state nitrogen isotope effects of $\mathrm{N}_{2}$ and $\mathrm{N}_{2} \mathrm{O}$ production in Paracoccus denitrificans. Appl. Environ. Microbiol., 65, 989-994.

[9] Wahlen, M. and Yoshinari, T. (1985). Oxygen isotope ratios in $\mathrm{N}_{2} \mathrm{O}$ from different environments. Nature, 313, $780-782$

[10] Yoshinari, T. and Koike, I. (1994). The use of stable isotopes to for the study of gaseous nitrogen species in marine environments. In: Lajtha, K. and Michener, R. H. (Eds.), Stable Isotopes in Ecology and Environmental Sciences. Blackwell Science, Malden, Mass, pp. 114-137.

[11] Brand, W. A. (1995). Precon: a fully automated interface for the pre-GC concentration of trace gases in air for isotopic analysis. Isotopes Environ. Health Stud., 31, 277-284.

[12] Matson, P. A., Vitousek, P. M., Livingstone, G. P. and Swanberg, N. A. (1990). Sources of variation in nitrous oxide fluxes in Amazonian ecosystems. J. Geophys. Res., 95, 16789-16798.

[13] Pérez, T., Trumbore, S. E., Tyler, S. C., Davidson, E. A., Keller, M. and de Camargo, P. B. (2000). Isotopic variability of $\mathrm{N}_{2} \mathrm{O}$ emissions from tropical forest soils. Glob. Biogeochem. Cycles, 14, 525-535.

[14] FAO (1990). Soil map of the world, revised legend. FAO, Rome, Italy.

[15] Menyailo, O. V. and Huwe, B. (1999). Activity of denitrification and dynamics of $\mathrm{N}_{2} \mathrm{O}-$ release in soils under six tree species and grassland in central Siberia. J. Plant Nutr. Soil Sci., 162, 533-538.

[16] StatSoft (1997). STATISTICA for Windows (Computer Program Manual). Tulsa, OK. 
[17] Ueda, S., Go, C.-S., Suwa, Y., Matsui, Y., Yamaguchi, F., Shoji, T., Noto, K., Sumino, T., Tanaka, A. and Matsufuji, Y. (1999). Stable isotope fingerprint of $\mathrm{N}_{2} \mathrm{O}$ produced by ammonium oxidation under laboratory and field conditions. In: International Workshop on the Atmospheric $\mathrm{N}_{2} \mathrm{O}$ Budget: An Analysis of the State of Our Understanding of Sources and Sinks of Atmospheric $\mathrm{N}_{2} \mathrm{O}$. Japan Nat. Inst. of Agro-Environ. Sci., Tsukuba, Japan.

[18] Nadelhoffer, K. J. and Fry, B. (1994). Nitrogen isotopes studies in forest ecosystems. In: Lajtha, K. and Michener, R. (Eds.), Stable Isotopes in Ecology and Environmental Science. Blackwell Science Publications, Oxford, Boston, pp. 22-44.

[19] Cifuentes, L. A., Fogel, M. L., Pennok, J. R. and Sharp, J. H. (1989). Biogeochemical factors that influence the stable isotpe ratio of dissolved ammonium in the Delaware Estuary. Geochim. Cosmochim. Acta, 53, 2713-2721.

[20] Hoch, M. P., Fogel, M. L. and Kirchman D. L. (1994). Isotope fractionation during ammonium uptake by marine microbial assemblages. Geomicrobiol. J., 12, 113-127.

[21] Montoya, J. P. and McCarty, J. J. (1995). Nitrogen isotope fractionation during nitrate uptake by marine phytoplankton in continuous culture. J. Plankton Res., 17, 439-464.

[22] Wada, E. and Ueda, S. (1996). Carbon, nitrogen, and oxygen isotope ratios of $\mathrm{CH}_{4}$ and $\mathrm{N}_{2} \mathrm{O}$ in soil ecosystems. In: Boutton, T. W. and Yamasaki, S.-I. (Eds.), Mass Spectrometry of Soils. Marcel Dekker, New York, pp. 177-204.

[23] Barford, C. C. (1997). Stable isotope dynamics of denitrification, PhD thesis, Harvard University, Cambridge, Mass. 